\title{
Physiological and genetic mechanisms underlying caste development, reproduction and division of labor in stingless bees
}

\author{
Klaus HARTFELDER ${ }^{\mathrm{a} *}$, Gustavo R. MAKERT ${ }^{\mathrm{b}}$, Carla C. JUDICE $^{\mathrm{c}}$, \\ Gonçalo A.G. PEREIRA ${ }^{\mathrm{c}}$, Weyder C. SANTANA ${ }^{\mathrm{d}}$, Rodrigo DALLACQUA ${ }^{\mathrm{d}}$, \\ Márcia M.G. BITONDI ${ }^{\mathrm{d}}$ \\ a Departamento de Biologia Celular e Molecular e Bioagentes Patogênicos, Faculdade de Medicina \\ de Ribeirão Preto, Universidade de São Paulo, Brazil \\ b Departamento de Genética, Faculdade de Medicina de Ribeirão Preto, Universidade de São Paulo, Brazil \\ c Departamento de Genética e Evolução, Instituto de Biologia, Universidade Estadual de Campinas, Brazil \\ d Departamento de Biologia, Faculdade de Filosofia, Ciências e Letras de Ribeirão Preto,
} Universidade de São Paulo, Brazil

Received 26 September 2005 - revised 29 November 2005 - accepted 23 December 2005

\begin{abstract}
Investigations on physiological and molecular mechanisms underlying developmental and reproductive differentiation in social bees center on the question of how different patterns of larval nutrition can affect hormonal dynamics and how these drive differential gene expression. Differential expression analyses and the generation of AFLP markers now enable us to re-examine the question of genetic caste determination in the genus Melipona. The comparison of vitellogenin expression in three species of stingless bees suggests divergence in regulatory mechanisms that directly relate to the mode of worker reproduction. As in honey bees, this indicates alternative functions for vitellogenin in the life cycle of adult workers. The diversity in life histories and their associated specific physiologies make the stingless bees a rich resource for information on evolutionary trajectories that have generated phenotypic plasticity in social Hymenoptera.
\end{abstract}

stingless bee / caste development / juvenile hormone / vitellogenin / worker reproduction / Apidae / Meliponini

\section{INTRODUCTION}

The caste syndrome in highly social insects is a life history trait that is based upon developmental pathways capable of generating alternative phenotypes. In most cases, alternative caste phenotypes and their differential reproductive potential result from an environmental stimulus that triggers a response in the endocrine system. This, in turn, drives preimaginal differentiation processes into alternative pathways, primarily during metamorphosis. Thus, not surprisingly, the hormones involved in caste development and reproductive physiol- ogy are juvenile hormone ( $\mathrm{JH})$ and ecdysteroids, the major morphogenetic and reproductive hormones of insects (Wheeler, 1986; Hartfelder, 2000; Hartfelder and Emlen, 2005). As such, the caste syndrome is built upon a basic groundplan of insect development and reproduction (West-Eberhard, 1996; Hunt and Amdam, 2005). Having set the general framework for the caste syndrome we next have to ask how life histories of different groups of social insects are linked to these basic physiological modules, and whether and how these can generate and explain the variability in developmental and reproductive traits.

* Corresponding author: khartfel@ rge.fmrp.usp.br

Dedicated to Dr. Warwick E. Kerr 
Why are stingless bees an interesting group to look for such traits? Their large number of species and genera, as well as the variability in ecological and behavioral traits make stingless bees a microcosm to look for correlative associations between life history traits on the one hand and physiological and genetic mechanisms underlying caste development, differential reproduction and division of labor on the other. In this review many of these observations on stingless bees will be contrasted with corresponding information for the honey bee.

\section{ROYAL CELLS, ROYAL FOOD AND ROYAL GENES - THE INITIAL TRIGGERS OF CASTE DEVELOPMENT}

All stingless bees follow a mass-provisioning strategy in caring for their brood, that is, brood cells built out of a wax and resin mixture are filled with well defined amounts of larval food regurgitated from the crops of nurse-stage workers. In several species, nurse-stage workers lay trophic eggs at defined positions within newly provisioned brood cells (Sakagami et al., 1963; Velthuis and Velthuis, 1998, and references therein; Silva-Matos et al., 2000). These eggs are eaten by the queen, or occasionally by another worker. Subsequently, the queen lays a reproductive egg on top of the liquid food mass, and the cell is immediately sealed. Since this sequence of events marks a critical aspect of colony reproduction (reproductive integration and competition), the exact sequence of behavioral events, that is, the temporal dynamics of cell construction, provisioning, egg-laying by workers (trophic and reproductive eggs) and queens, and even of cell sealing, is highly species-specific (Sakagami et al., 1973; Sakagami and Zucchi, 1974). This sequence of events in the cell Provisioning and Oviposition Process (POP) has been split into discrete units and has been intensely studied and classified in terms of possible phylogenetic implications (Zucchi et al., 1999; see also references in other reviews within this Special Issue).

\subsection{Trophogenic control of caste development}

With respect to caste development it is important to know whether the larval food that stingless bee workers regurgitate into brood cells contains specific compounds that might favor queen development, just like royal jelly does in the honey bees, or whether it is simply a matter of food quantity. This question also leads directly to the major dividing line between the trigonine group of stingless bees and the genus Melipona in terms of the role of larval food in the triggering of queen/worker developmental pathways (Michener, 1974; Sakagami, 1982). In this respect, all trigonine genera (we use here the colloquial terminology where "trigonines" is taken to mean "all stingless bee genera, except Melipona") capitalize on quantitative differences in larval food that is being made available to the growing larvae (Figs. 1A, 1B), but they have chosen different strategies. In genera with a clustered brood cell arrangement (Leurotrigona, Frieseomelitta), all cells are of similar size (Fig. 1A), so they would normally give rise to workers or males. Yet, when queens are to be reared, a second cell is constructed closely apposed over a previously built one. Once the larva developing in the lower cell has consumed its portion of larval food it then penetrates into the upper cell and consumes an additional portion of larval food (Faustino et al., 2002). The question of how a larvae in a closed cell may come to know that there is a second food portion waiting in a neighboring cell may actually be a matter of information transfer from workers through a novel structural element connecting the two cells. Faustino et al. (2002) showed that workers construct a special feeding connection from the original to the auxiliary cell. Since this mode of queen production has so far only been carefully recorded under conditions of emergency queen rearing, it is still an open question whether the same mechanism of queen determination is also used for queen production under queenright conditions, for colony reproduction.

The more frequent situation encountered in most trigonine genera is a brood nest with an architecture of horizontal combs separated by pillars (Michener, 1974). At the margins of these combs, the workers occasionally build royal cells of much larger size, and these cells are provisioned with royal quantities of larval food, usually double or triple the amount deposited in normal cells (Fig. 1B). A larva in a queen cell can thus feed much longer than a worker larva and stops growing and enters metamorphosis at a much larger size (Hartfelder 


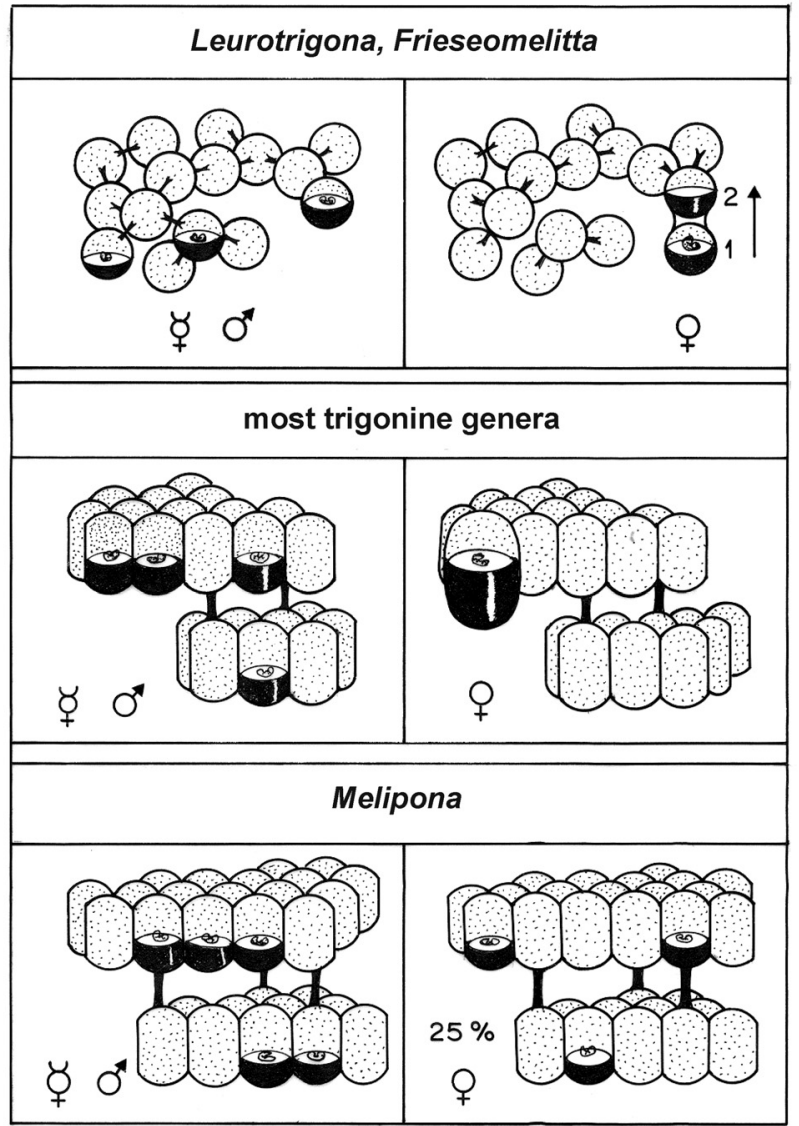

Figure 1. Modes of queen rearing in stingless bees. (A) In the brood nest of the trigonine genera Leurotrigona and Frieseomelitta, brood cells are arranged in a cluster where individual cells are separated from each other by pillars. Brood cells for workers and males are of the same size (left). For queen rearing (right), a second brood cell is built over an already finished one containing a female larva. After this larva has consumed the food portion in cell 1 it perforates the wall to cell 2 and consumes its contents as well. (B) The brood nest of most trigonine genera is laid out in horizontal combs. Brood cells for workers and males are of the same size (left). For queen rearing (right), large cells are built at the margin of a comb, and these are filled with a large food portion before the queen lays an egg and the cell is sealed. (C) In the genus Melipona, brood cells of workers, males and queens are all of the same size and contain the same amount of larval food. Queens (right) may emerge from up to $25 \%$ of the brood cells containing female offspring. For references see text. and Engels, 1992). As a consequence of the consumption of larger amounts of larval food by queen larvae in all trigonines, the onset of metamorphosis is much delayed and total developmental time of queens is longer when compared to workers (Camargo, 1972a).

Ever since the early description of brood nest architecture in the genus Melipona (Ihering, 1903), this stingless bee genus has been considered a curiosity in the context of caste development because no specific queen cells could be found on the brood combs (Fig. 1C). Instead, queens were found to develop in cells of the same size as those giving rise to workers and males. But it is not only in this respect that Melipona species differ from the trigonine genera, they also produce queens at much higher frequencies (up to 20-25\%) (Kerr, 1946, 1948, $1950 \mathrm{a}, \mathrm{b})$ than the trigonine species (usually only $1-2 \%$ of queens in female brood), and Melipona queens develop faster than workers (Kerr, 1948; Kerr et al., 1966).

This variability in queen cell structure and larval food portions in stingless bees and their phylogenetic proximity to the honey bees has prompted questions such as, is quantity of larval food more important than quality, and who is in control of gyne production, the workers, the queen, or even the larva itself? The frequency of queen rearing could be increased to nearly $100 \%$ in trigonine species by provisioning larvae reared in artificial cells with double to triple amounts of larval food that was collected and mixed together from other newly provisioned cells (Camargo, 1972a; Buschini and Campos, 1995). This apparent prevalence of food quantity over quality in most stingless bees was also corroborated when the specific 
composition of larval diets was biochemically analyzed (Hartfelder and Engels, 1989). The nutritional signal for caste development in stingless bees is, thus, clearly different from that in honey bees which rely on a nutritional switch from royal jelly to worker jelly in the late larval instars of worker brood (for review see, Rembold et al., 1974; Hartfelder, 1990). In essence, this means that honey bee nurses switch fourth to fifth instar worker larvae from a high quality glandular food to a pollen and nectar supplemented diet. The result is that queens grow faster during these last instars and enter and complete metamorphosis more quickly than workers do. In contrast, the trigonine genera of stingless bees do not rely on a nutritional switch, but on a larger food supply for queen larvae, resulting in an extended feeding period and, consequently longer duration of preimaginal development for queens.

Once again, Melipona seems to run contrary to the rule because a minor increment in the amount of food available to larvae could increase the frequency of queens, but it could not be driven beyond the $25 \%$ threshold (Camargo et al., 1976). And when investigating the strong seasonal variation observed in the percentage of queens in female brood, Kerr et al. (1966) noted that the frequency of queen production in Melipona is inversely proportional to the number of workers that are required to provision a brood cell. Since it is usually under favorable conditions of colony provisioning that less workers are needed to fill each brood cell, one cannot exclude that minor differences in food quality may actually tip the balance to favor queen development in a considerable portion of female brood. So far, however, there is no data on (seasonal) qualitative variation in larval food of Melipona species, mainly because we have no clues what to look for in the food.

In terms of who is in control of queen production, in the trigonine genera it is the workers that hold most of the direct power over the caste fate of the brood since they build the cells either closely together or of different size (Sakagami, 1982). In the genus Melipona it seems, at first sight, that caste fate is a characteristic of the larva itself, but then, larval food still has a modulatory effect on this decision. These aspects are undoubtedly interesting in terms of sociobiological questions and for modeling social organization (Ratnieks, 2001). Less obvious may be that they also have important implications when it comes to underlying developmental mechanisms and how they may have evolved.

\subsection{Melipona, a special case?}

The genus Melipona has gained singular status ever since Kerr (1946, 1948, 1950b) first proposed that the exceptionally high and near $25 \%$ frequency of queens emerging from cells of female brood may be explained by a genetic predisposition to caste fate. He proposed a two loci model, each with two alleles, where only double heterozygote females should become queens. Since the mother queen would always be double heterozygous at these loci, this prediction would be fulfilled in exactly $25 \%$ of all females (Kerr, 1948, 1950a, b). In strong colonies and during certain times of the year one may actually observe such a proportion of emerging queens, yet, most of the time, queens emerge at much lower queen-to-worker ratios (Velthuis, 1976). Interestingly, however, the queen frequency in brood is much less variable during the seasons than is the male/female ratio (Velthuis et al., 2005). The lower than predicted proportion of queens produced in colonies under natural conditions has been attributed to the larval food effect mentioned above, where a suboptimal feeding regime would redirect the development of genetic queens into a worker phenotype (Kerr and Nielsen, 1966; Kerr, 1969, 1974, Camargo et al., 1976; Maciel-Silva and Kerr, 1991).

So far, two different approaches have been used to find evidence for or against a genetic predisposition to caste. The first approach was to look for morphological markers that would distinguish true workers from genetic queens disguised as workers. The first morphological marker for genetic queens was proposed by Kerr and Nielsen (1966) who noted that fusion of the abdominal ganglia during metamorphosis follows different dynamics in queens and workers. But this is a transient developmental marker, because in the adult stage the number of fused abdominal ganglia is the same for the two castes. The caste difference in the temporal pattern of ganglia fusion has now found an explanation in the endocrine signatures of the two castes, with ecdysteroids acting as the main players (Pinto et al., 2003; and see below, 


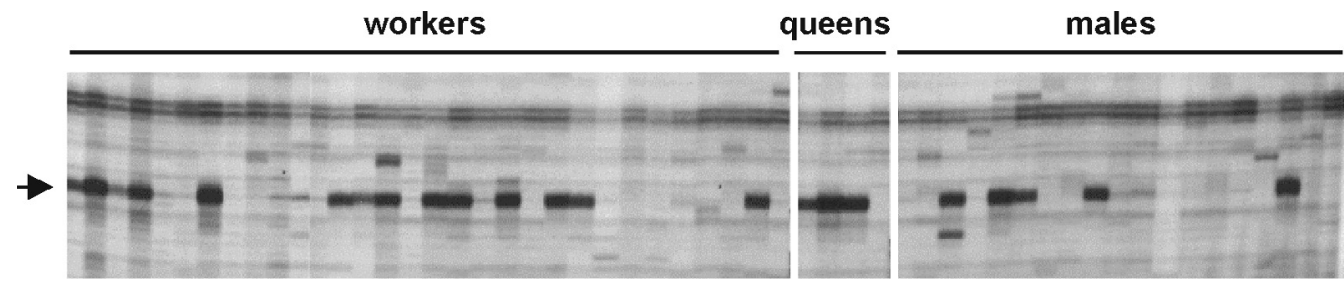

Figure 2. Amplified Fragment Length Polymorphism (AFLP) markers visualized by electrophoresis in a sequencing gel. DNA was extracted from bees emerging from a single brood comb of a Melipona quadrifasciata colony. After digestion by restriction enzymes, adapter primers were ligated to the fragments permitting selective amplification. The section of a gel in this figure shows a band (arrow) that is present in $42 \%$ of the workers, in $75 \%$ of the queens, and in $26 \%$ of the males. This AFLP marker is one of the candidates for a genetic mechanism acting in caste determination in the genus Melipona.

Sect. 2.3). The other morphological marker proposed to detect genetic queens was the number of tergal glands (Cruz-Landim et al., 1980).

A completely different approach to test for a genetic predisposition of caste made use of the finding that queen development in stingless bees in general (Melipona and trigonine genera) can be induced in almost $100 \%$ of the female brood when larvae are treated with $\mathrm{JH}$ or $\mathrm{JH}$ analogs during the spinning stage of the last instar (Campos et al., 1975, 1983; Velthuis and Velthuis-Kluppell, 1975; Campos, 1978, 1979, 1983; Buschini and Campos, 1995; Bonetti et al., 1995). Since only $25 \%$ of these $\mathrm{JH}$-induced queens should actually have the queen genotype, the frequency of gynes emerging in colonies headed by $\mathrm{JH}$-induced queens should vary from $0 \%$ (if the parental pair had identical alleles at both loci) to $25 \%$ (if the queen and her mating partner had different alleles at both caste loci). This seemed like an experimentally feasible approach (Velthuis, 1976) since queens can be mated to single males in mating boxes (Camargo, 1972b). Up to now, however, none of the many studies investigating $\mathrm{JH}$ action in stingless bees really gave a conclusive answer to this question, because JH-induced queens apparently have problems in establishing colonies. Based on recent evidence we consider the lack in queenlike behavior in $\mathrm{JH}$-induced queens as a physiological phenomenon because of the surprisingly high divergence in gene expression patterns for JH-induced queens when compared to newly emerged natural queens (Judice et al., 2006; and see below Sect. 2.4).
Since morphological markers did not provide the desired resolution, and offspring analysis of $\mathrm{JH}$-induced queens appears to be hampered by the queens' reproductive biology, we recently invested in a large-scale screening of genetic markers. We established a protocol to generate large numbers of Amplified Fragment Length Polymorphism (AFLP) markers (Makert et al., 2006) and have started to look for markers that segregate with caste. One of these putative markers is shown in Figure 2. In this set of bees, which is a single age cohort of a single colony, we detected this marker in three of the four virgin queens (75\%), in 13 of the 31 workers (42\%), and in 5 of the 19 males (26\%). We detected at least six more markers with similar segregation ratios. While these data are still preliminary they already provide support to the genetic predisposition hypothesis for caste determination in Melipona, although the final model derived from AFLP markers may actually look quite different from the originally proposed two loci/two alleles model.

These approaches were all designed to explicitly test for a genetic predisposition of caste under the Kerr hypothesis. As this is a classic Mendelian segregation model, it has its focus on the individual genotype, and consequently, considerations on individual versus colony fitness acting in this system did not play a major role in explanations on how this system may have evolved (Kerr, 1969, 1974, 1987). A more recent approach focuses exactly on these fitness aspects to explain the high number of queens produced in Melipona colonies (Ratnieks, 2001; Wenseleers et al., 2003). These authors suggest that caste fate in Melipona 
females can be decided by the larvae themselves. Their inclusive fitness model predicts an optimal queen emergence frequency of $20 \%$ in female brood of colonies headed by a singlemated queen that produces not only the female but also all the male offspring. In contrast, if the male offspring were all worker-produced, the optimal queen emergence frequency in such a colony would be $14 \%$. This hypothesis finds support in the fact that there are only minor quantitative differences in larval food available to female larvae, so control by workers through cell provisioning is only very limited. Even though plausible and attractive on theoretical grounds, the "self determination" hypothesis for caste fate has a drawback as it does not provide any lead on what might be the underlying developmental mechanism(s) for the queen/ worker decision.

\subsection{Hormonal regulation of caste development}

Independent of what is the nature of the initial trigger of caste determination, this information has to be transmitted to all tissues and cells in a coordinated manner to synchronize and integrate the development of the segmental morphological structures and internal organs during metamorphosis. This integrative function is played out by the endocrine system through the release of $\mathrm{JH}$ and ecdysteroids by the corpora allata and the prothoracic gland, respectively. The role of $\mathrm{JH}$ in caste development of stingless bees has been extensively explored by the application of $\mathrm{JH}$ and $\mathrm{JH}$ analogs. These experiments unambiguously demonstrated the existence of a JH-sensitive period for the queen/worker decision in the spinning phase of the last larval instar (Campos et al., 1975, 1983; Velthuis and Velthuis-Kluppell, 1975; Campos, 1978, 1979; Bonetti et al., 1994, 1995; Buschini and Campos, 1995). Endogenous JH levels during larval development have, so far, only been measured for a single species, Scaptotrigona postica (Scaptotrigona aff. depilis) (Hartfelder and Rembold, 1991), and the observation of strikingly higher JH levels in queens have fully confirmed the assertion of a JH-critical period in the spinning phase of the last larval instar.

For $S$. postica, we also determined the larval and pupal ecdysteroid titer profile and observed major caste differences in the prepupal and pupal stages. During these stages, the ecdysteroid titer was much higher in queens than in workers (Hartfelder and Rembold, 1991). Ecdysteroid function has been investigated in $M$. quadrifasciata with respect to the caste-specific program of abdominal ganglia fusion (Pinto et al., 2003). This study revealed that ventral nerve cord preparations of $M$. quadrifasciata larvae exposed in vitro to a physiological concentration of 20-hydroxyecdysone undergo rapid shortening of connectives and show programmed cell death in response to this hormone. In vivo, these events would represent the first steps in the fusion process of the abdominal ganglia described by Kerr and Nielsen (1966).

The ecdysteroid titer profiles for pupae of highly eusocial bees have now been investigated for the honey bee (A. mellifera) and two stingless bees ( $S$. postica and M. quadrifasciata). With data obtained for the latter species (Pinto et al., 2002) it became possible to relate the different parameters in the modes of caste determination (trophogenic versus genetic, early versus late nutritional signal, and fast versus slow developing queens) with their characteristic endocrine signatures. In the fast developers (Apis and Melipona queens), the pupal ecdysteroid titer has its major peak earlier in the pupal phase than in the slow developers (Scaptotrigona queens), when compared to their respective workers. The phylogenetic difference (honey bees versus stingless bees) is reflected in the peak levels that the ecdysteroid titer attains in the early pupal phase and in the way the titer gradually declines in the late pupal phase. In honey bees, queens and workers differ only in the timing of the pupal peak but not in peak height, whereas in the stingless bees, the two castes differ with respect to both timing and levels of the ecdysteroid titer peak, which is always higher in the queen caste. With respect to the late pupal ecdysteroid titer, this is higher in honey bee queens than in workers, whereas in the two stingless bees it is the workers that have higher titers than the queens. These comparative analyses show to what extent the endocrine system can respond differently to caste-determining stimuli, and which aspects in this response may represent phylogenetic constraints. Since the pupal ecdysteroid titer is a major regulating factor for the pigmentation 
program of the adult cuticle of bees (Zufelato et al., 2000), and probably also for other morphogenetic programs executed in the pupal period of metamorphosis, these titer differences should have prime importance for casteand group-specific characteristics apparent in the adult life stages of the highly eusocial bees.

\subsection{From caste to BLAST: differential gene expression in Melipona queens and workers}

In stingless bees, the results of caste differentiation processes and their hormonal control have so far been evaluated primarily through their effects on morphological character expression and effects on allometric change (Velthuis and Velthuis-Kluppell, 1975; Campos, 1978; Hartfelder and Engels, 1992), yet these effects are far removed from the direct targets of hormonal regulation. Since both JH and ecdysteroids exert their effects through nuclear hormone receptors (Barchuk et al., 2004) that impact directly on gene expression, the progress on differential gene expression analysis in honey bee caste development (Corona et al., 1999; Evans and Wheeler, 1999, 2000; Hepperle and Hartfelder, 2001; Guidugli et al., 2004) and in bumble bees (Pereboom et al., 2005) has prompted us to investigate differential gene expression in caste development of stingless bees. These studies were performed on the genus Melipona due to its distinct mode of caste determination. Yet, instead of looking at differential gene expression during the late larval stages, we focused on newly emerged adult bees. At this stage, queens and workers are morphologically distinct, but they are not yet influenced by social interactions that may impact gene expression soon after the bees participate in colony life.

Two different methodological approaches were employed to investigate differential gene expression in Melipona queens and workers. The first one was a Differential Display Reverse Transcription (DDRT) PCR strategy (Judice et al., 2004) which permitted cloning and sequencing of 14 Expressed Sequence Tags (ESTs). These represent 12 genes that are overexpressed in newly emerged workers and two genes overexpressed in queens. Ten of these Melipona ESTs are also represented in the EST library generated from honey bee brain
mRNA (Whitfield et al., 2002), and nine of the Melipona ESTs showed significant blastx matches to sequences deposited in the nonredundant (nr) database (GenBank). These matching ESTs could be grouped into four Gene Ontology categories: transcriptional regulators, cell signaling, structural genes, and metabolic enzymes. Interestingly, the two transcriptional regulators overexpressed in workers are both putatively involved in repression and silencing of gene expression, and the structural genes encode muscle-specific proteins, indicating structural differences in queen and worker flight muscle. The metabolic enzyme overexpressed in workers represents a member of the cytochrome-P450 family, and thus, reflects a general pattern apparent in caste development of social bees, namely, the prominent role of energy metabolism in the caste syndrome (Corona et al., 1999; Guidugli et al., 2004; Pereboom et al., 2005).

The second strategy towards identifying caste-specific gene expression in M. quadrifasciata was a high throughput approach that has several advantages over DDRT-PCR. The Representational Difference Analysis (RDA) is a version of a suppression subtractive hybridization strategy, and it was used to generate two libraries enriched for queen and for worker transcripts, respectively. This approach generated 1278 high quality ESTs, representing 337 unique sequences (Judice et al., 2006). As in the DDRT-PCR study on caste-specific gene expression in Melipona, this approach also revealed a much broader functional spectrum of transcripts in the worker library (22 unique sequences with exclusive occurrence in workers, versus 5 exclusive to queens). At first view this would indicate that workers are transcriptionally more complex than queens, but this must be taken with a caveat, as it may actually reflect an annotation problem. We recently performed a reannotation of honey bee ESTs that were isolated in differential gene expression screens for castes (Evans and Wheeler, 1999, 2000; Corona et al., 1999; Hepperle and Hartfelder, 2001). Prior to the release of the honey bee genome sequence, many of these ESTs were listed as "no matches" that fell through the analysis because they mapped to little conserved 3'UTR regions. In this re-annotation it now became apparent that queens are transcriptionally quite complex and, even more importantly, 


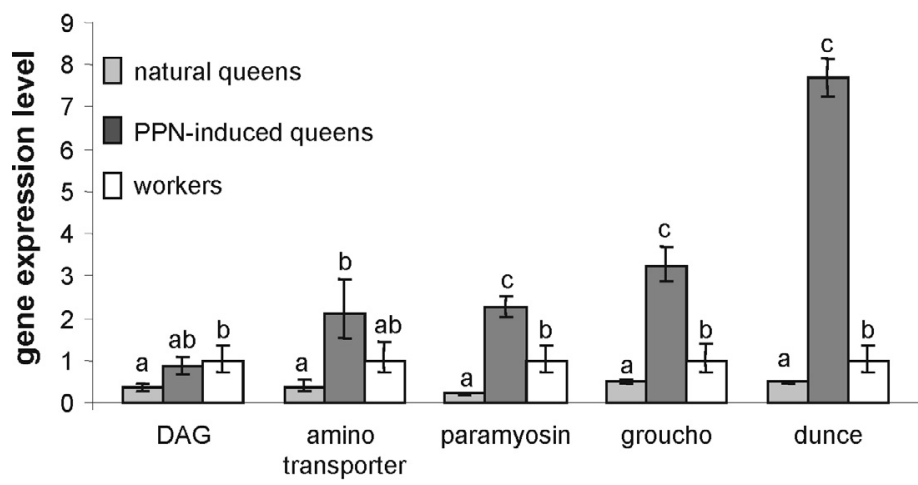

Figure 3. Comparative gene expression (realtime RT-PCR) in newly emerged queens and workers, and in queens induced by application of the juvenile hormone analog pyriproxifen (PPN). The studied genes were obtained from an RDA library where they were initially characterized as overexpressed in workers (Judice et al., 2006). Queens induced by PPN application in the last larval instar showed an expression pattern that was clearly distinct from that observed in naturally reared queens. Either they showed an intermediate expression level between natural queens and workers (DAG gene), or they displayed an expression level that even exceeded that of workers. Means and standard errors of relative expression differences are shown. Statistical differences for means are indicated by different letters over bars (modified after Judice et al., 2006).

seem to express considerably more "novel" genes than workers, that is, genes which do not have functionally annotated homologs in any other genome.

To validate the RDA results for Melipona queens and workers, we tested the differential expression of 5 worker unique sequences by quantitative (realtime) RT-PCR. In this quantitative expression analysis we also included mRNA samples of newly emerged queens produced by application of the $\mathrm{JH}$ analog pyriproxifen (PPN) to last instar larvae. Contrary to expectation, the hormone induced queens did not show the queen-typical expression pattern for these genes (Judice et al., 2006). In four of these, the JH-induced queens even outmatched the workers (Fig. 3). This quite astonishing result apparently indicates a separation between hormonal effects on adult phenotype and corresponding gene expression pattern. It also represents a potentially interesting facet of the genetic predisposition to caste proposed for the genus Melipona. It may actually explain why attempts to test the genetic caste determination hypothesis with $\mathrm{JH}$ induced queens have failed, because morphological phenotype and gene expression patterns apparently do not match up in $\mathrm{JH}$-induced queens.
A second source of hormonal regulation, acting possibly in addition to the $\mathrm{JH}$ and ecdysteroid cascades, also became apparent through the differential gene expression analyses. This strategy led to the cloning of a $320 \mathrm{bp}$ fragment with significant blastx similarity $\left(6 \mathrm{e}^{-12}\right)$ to the Drosophila gene lilliputian (Judice, unpublished). In Drosophila, lilliputian acts not only as a regulator of cell size, where it integrates with PTEN in the insulin signaling pathway (Wittwer et al., 2001), but it is also involved in axis formation through the decapentaplegic (Dpp) pathway (Su et al., 2001). The detection of a putative lilliputian homolog in caste development of a stingless bee may, thus, represent a glimpse at a gene expression network that integrates the growth-regulating insulin signaling pathway with the morphogenetic regulators, juvenile hormone and ecdysteroids.

The entire list of differentially expressed genes in Melipona queens and workers has now been made available and searchable at http:// www.lge.ibi.unicamp.br/abelha, after user registration. This site also provides information on electronic Northerns that represent transcript abundance in the respective subtractive libraries. Current efforts are made to generate microarray chips for $M$. quadrifasciata genes as a tool for high-throughput gene expression analysis in this stingless bee. 


\section{PHYSIOLOGY OF REPRODUCTION AND DIVISION OF LABOR}

Similar efforts in functional genomics performed on the honey bee are already dramatically changing how we view the caste syndrome and division of labor in eusocial bees (Evans and Wheeler, 2001; Kucharski and Maleszka, 2002; Cash et al., 2005). Yet, this big picture is mainly derived and based on studies and experiments performed to a great extent on the honey bee only. There is very little information available on the genomic and physiological regulatory architecture underlying reproduction and division of labor in the stingless bees. Yet, even though still preliminary in many aspects, results obtained for a select set of stingless bees already indicate that surprises are awaiting with respect to the endocrine regulation of fertility and division of labor.

One of our research projects investigates the $\mathrm{JH}$ and ecdysteroid titer profiles in M. quadrifasciata queens and workers. With respect to ecdysteroid titers, both castes showed a minor peak during the first days after emergence, and subsequently their hemolymph titers remained at basal levels throughout the adult life cycle (Hartfelder et al., 2002). This finding compared favorably well with that obtained for honey bees (Robinson et al., 1991; Hartfelder et al., 2002), and it sets the highly eusocial honey bees and stingless bees clearly apart from the primitively eusocial bumble bees. In the latter, ovarian ecdysteroid levels and the ecdysteroid titer correlate with reproductive activity and social dominance (Bloch et al., 2002; Geva et al., 2005).

Only preliminary results are, so far, available on the JH titer in adult stingless bees. Such RIA measurements are currently being performed on M. quadrifasciata queens and workers. For queens, the only results available are for newly emerged gynes, revealing very high titers (around $300 \mathrm{pg} \mathrm{JH}-\mathrm{III}$ equivalents per $\mu \mathrm{L}$ hemolymph) at this early age. For workers, JH titers were measured in a pilot study where they were kept for up to 30 days in Petri dishes in small social units. Under these conditions, the $\mathrm{JH}$ titer of workers started out at around $25 \mathrm{pg}$ (JH-III equivalents per $\mu \mathrm{L}$ hemolymph) at emergence. It gradually increased and reached a maximum of around $75 \mathrm{pg}$ between days 7 and 8 and then rapidly declined again to basal levels, fluctuating around $25 \mathrm{pg}$ until the end of the observation period. Provided that this result can be confirmed by RIA analysis of JH titers in workers kept under normal conditions and performing activities corresponding to their respective age (Waldschmidt and Campos, 1997), stingless bees would differ quite drastically from honey bees in the physiological parameters underlying division of labor in workers and also with respect to the association of $\mathrm{JH}$ and reproductive activity in queens. If confirmed in a more extensive study, these findings clearly will have an impact on how we perceive the role of $\mathrm{JH}$ in reproduction and behavioral development in eusocial Hymenoptera (Robinson and Vargo, 1997; Sullivan et al., 2000; Bloch et al., 2002).

Even though the older Melipona workers were clearly different from honey bee workers with respect to their hormone titers, the two species showed traces of similarity in the young bees. Like in the honey bee, where a small $\mathrm{JH}$ peak has been detected in 2-4 day-old honey bee workers (Elekonich et al., 2003), M. quadrifasciata workers also showed a peak in their JH titers in the first days after emergence. Such a minor peak at an early adult age was also apparent for the ecdysteroid titer of $M$. quadrifasciata workers and for honey bee workers (Hartfelder et al., 2002). The physiological significance of these early $\mathrm{JH}$ and ecdysteroid peaks in young workers of social bees is still a mystery, but it coincides with a transition from a still immature behavioral state to that of a worker bee participating in activities relevant to colony performance. This early adult hormonal signature may also be relevant to programs involved in determining adult life span, as recently shown for winter bees infested with Varroa mites. These bees had an altered ecdysteroid profile in the first days after emergence and showed immunological characteristics related to reduced life span (Amdam et al., 2004).

The main parameter of female fertility in insects, the vitellogenin titer in hemolymph has been profoundly investigated in the honey bee, but only preliminarily so in stingless bees. The study by Engels and Engels (1977) on S. postica and M. quadrifasciata showed that queens, as expected, had a much higher vitellogenin titer than workers. Less clear and evident was, however, the relationship between the vitellogenin titer and the program of division of labor in adult workers in these stingless bees. 
In honey bees, the vitellogenin titer in workers increases when they are approximately 7 days old, and it reaches a maximum while they are performing nursing activities (Hartfelder and Engels, 1998). At the transition from nursing to foraging behavior, the vitellogenin titer declines and stays at low levels for the remainder of the adult life cycle. The vitellogenin titer of honey bee workers, thus, shows exactly the opposite profile to the JH titer (Robinson et al., 1991). In accordance with this, experimental evidence had already previously suggested an inhibitory role of JH on vitellogenin expression (Rutz et al., 1976) and its relation to the behavioral transition from nursing to foraging behavior (Jaycox, 1976). It is only in the late pupal stages that JH actually acts as an activator of vitellogenin synthesis in honey bees queens and workers (Barchuk et al., 2002), just as it does in the adult life cycle of many other insects (Raikhel et al., 2005). This dynamic behavior of the vitellogenin titer has been confirmed not only at the level of protein titers in hemolymph, but also by the temporal expression pattern of the recently sequenced honey bee vitellogenin gene (Piulachs et al., 2003).

The honey bee vitellogenin sequence has now been used to clone and partially sequence the vitellogenin gene of $M$. quadrifasciata (Andrade and Simões, unpublished). Due to its high conservation, the honey bee vitellogenin primers could also be employed to study the temporal expression profiles in a set of stingless bee species that show interesting differences with respect to worker reproduction. These first results already show a completely different picture from that observed in the honey bee. First of all, vitellogenin gene expression could be detected by semiquantitative RT-PCR throughout the entire pupal stage in all three stingless bee species (Fig. 4), quite different from the honey bee, where vitellogenin expression appears to be strongly suppressed by the high ecdysteroid titer (Guidugli et al., 2005). This already could reflect a major change in the regulatory architecture underlying vitellogenin gene expression. Second, vitellogenin transcript and protein levels are rather disparate in stingless bees, indicating additional control at the translational level or in the secretion process. Third, the three stingless bee species differ considerably in how they modulate vitellogenin gene expression and its corresponding hemolymph protein level.
A

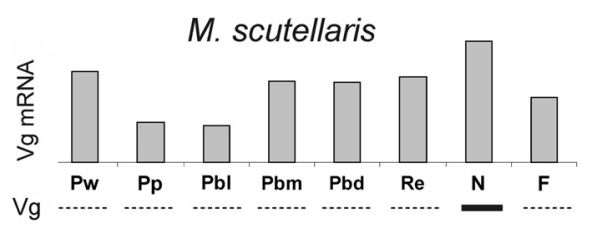

B F. varia

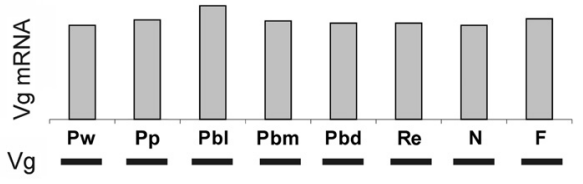

C S. postica
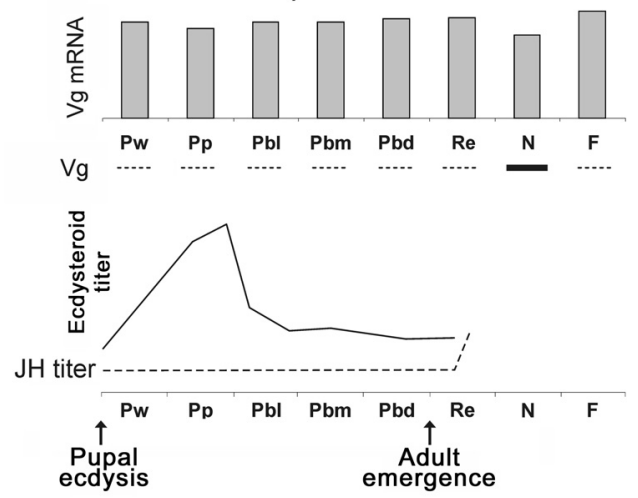

Figure 4. Developmental patterns of vitellogenin gene expression (determined by RT-PCR) and vitellogenin titer (determined by Western blot analysis) in hemolymph of workers representing three stingless bee genera. (A) In Melipona scutellaris, the level of vitellogenin transcription gradually increases during pupal development, as the ecdysteroid titer diminishes. Transcription reaches a peak in nurse stage workers, when vitellogenin becomes clearly detectable in hemolymph. (B) In Frieseomelitta varia, vitellogenin gene expression appears to be constitutive in pupae and in adult workers, and also, the vitellogenin titer shows no age-related modulation. Together with the fact that in $F$. varia workers the ovaries degenerate completely during pupal development, this finding strongly suggests alternative functions for this protein. (C) In Scapototrigona postica, vitellogenin gene expression also appears to be constitutive during pupal development and in the adult stages, but the presence of vitellogenin protein in the hemolymph could only be evidenced in the nurse bee stage. $\mathrm{Pw}, \mathrm{Pb}, \mathrm{Pbl}$, $\mathrm{Pbm}, \mathrm{Pbd}$ are pupal stages characterized by progressive eye and body pigmentation. Re, N, F are newly emerged workers, nurses, and foragers, respectively. The pupal ecdysteroid titer profile is a composite representation for $M$. quadrifasciata (Pinto et al., 2002), and S. postica (Hartfelder and Rembold, 1991). 
Table I. Patterns of worker reproduction under queenright conditions. The listing of stingless bee species within each reproductive type is far from complete and is only intended to provide examples; for further references see Sakagami (1982), Engels and Imperatriz-Fonseca (1990) and Toth et al. (2004).

\begin{tabular}{|c|c|c|}
\hline Type of worker reproduction & Species & References \\
\hline $\begin{array}{l}\text { Ovaries active in presence of queen, } \\
\text { workers produce reproductive and } \\
\text { trophic eggs }\end{array}$ & $\begin{array}{l}\text { Melipona subnitida } \\
\text { Melipona favosa } \\
\text { Paratrigona subnuda } \\
\text { Scaptotrigona postica }\end{array}$ & $\begin{array}{c}\text { Koedam et al., } 1999 \\
\text { Chinh et al., } 2003 \\
\text { Toth et al., 2002 } \\
\text { Sakagami and Zucchi, 1963; Beig, } \\
\text { 1972; Paxton et al., } 2003\end{array}$ \\
\hline $\begin{array}{l}\text { Ovaries active in presence of queen, } \\
\text { but workers produce primarily or only } \\
\text { trophic eggs }\end{array}$ & $\begin{array}{l}\text { Tetragonisca angustula } \\
\text { Trigona carbonaria } \\
\text { Geotrigona mombuca }\end{array}$ & $\begin{array}{c}\text { Grosso et al., } 2000 \\
\text { Green and Oldroyd, } 2002 \\
\text { Silva-Matos et al., } 2000\end{array}$ \\
\hline $\begin{array}{l}\text { Ovaries mostly inactive, no trophic eggs } \\
\text { but occasional laying of reproductive } \\
\text { eggs }\end{array}$ & Friesella schrottkyi & $\begin{array}{l}\text { Imperatriz-Fonseca and Kleinert, } \\
1998\end{array}$ \\
\hline $\begin{array}{l}\text { Ovaries inactive in the presence of the } \\
\text { queen }\end{array}$ & Leurotrigona muelleri & Sakagami, 1982 \\
\hline $\begin{array}{l}\text { Ovaries degenerate during pupal } \\
\text { development }\end{array}$ & Frieseomelitta varia & Boleli et al., 1999 \\
\hline
\end{tabular}

In the genus Melipona, nurse-stage workers produce not only trophic eggs, but also reproductive eggs and, thus, they contribute significantly to male production (Tab. I). Accordingly, vitellogenin protein is detected in hemolymph primarily during the nursing stage (Fig. 4A). In addition, vitellogenin transcription in the pupal stage most closely approximates to the pattern shown in honey bees. In Frieseomelitta varia workers, the ovary anlagen degenerate completely during metamorphosis (Boleli et al., 1999), thus disabling adult workers from producing any type of egg. In this case, vitellogenin appears to be expressed constitutively (Fig. 4B). This is quite a surprising finding in view of the fact that these workers invest heavily in producing a protein for which they apparently have no use. This puzzle may be resolved once we consider that vitellogenin may actually be involved in processes other than reproduction. Such additional roles have recently been demonstrated for honey bee vitellogenin which was found to be associated with immune system integrity and, consequently, longevity of worker bees (Amdam et al., 2004). Such findings can provide a lead as to where to look for vitellogenin functions, even in the sterile Frieseomelitta workers. Stingless bee workers appear to live about 20 days longer than honey bees (Bego, 1982).
Scaptotrigona postica workers present an intermediate picture when compared to the previous two stingless bees. Vitellogenin transcript levels are not (negatively) correlated with ecdysteroids during the pupal stage, but the protein makes its appearance in hemolymph primarily during the nurse bee stage (Fig. 4C). These results confirm a previous study that showed a strong correlation between vitellogenin titer and ovary size in relation to worker age (Engels and Engels, 1977).

To make sense of these disparate patterns of vitellogenin expression in workers of highly eusocial bees we will have to consider them in relation to life tables and task performance. At least in the honey bee, vitellogenin expression, together with the hemolymph JH titer, constitutes the primary regulatory machinery for behavioral development (Amdam and Omholt, 2002). Studies on behavioral development, unfortunately, may still be called the blind spot in stingless bee biology. Much ethological work has been dedicated to the complex behavioral interactions between the queen and workers in the POP context (Sakagami, 1982; Zucchi et al., 1999) in normal colonies, and in a particularly fine example, also in artificial mixedspecies colonies (Silva, 1977). Yet, the "who does what and when" in the colony has little been explored. Fortunately, two of the focal 
species of this review, S. postica and M. quadrifasciata, have been reasonably well studied in terms of worker life tables (Bego, 1982; Waldschmidt and Campos, 1997). These studies have revealed that stingless bees are much more plastic in their age-related tables of task performance, reflecting either a higher level of idiosyncrasy (workers remain on the respective task longer) or a higher degree of flexibility in switching tasks, possibly as a consequence of smaller colony size and the necessity for "filling in when there is need". Colony size varies considerably within the stingless bees (NogueiraNeto, 1997), from honey bee-sized colonies in Trigona and Scaptotrigona species to colony sizes comprising only a few hundred workers (Plebeia, Melipona, and many other genera), so, their worker life tables and associated task performance may actually look quite different. A closer look at vitellogenin and JH titers in workers of known age and task may, in the future, provide insight into the regulatory architecture underlying division of labor in stingless bee workers. The above mentioned results on vitellogenin expression patterns in stingless bees only opened the trail and certainly leave this question far from being answered, because, in this study we controlled only for task (nurse of forager) but not for worker age. In fact, future studies may profit considerably when comparing stingless bees not only to honey bees, but also to bumble bees. Similarities between stingless bees and bumble bees emerge not only in the reproductive biology of workers (egg-laying in the presence of the queen) but also in an apparently more flexible and JH-independent system of division of labor (van Doorn, 1987; Cameron and Robinson, 1990; O’Donnell et al., 2000).

\section{DEVELOPMENT OF THE WORKER REPRODUCTIVE SYSTEM AND WORKER REPRODUCTION IN STINGLESS BEES - "EVERYTHING GOES"?}

The results presented above on vitellogenin protein titers in hemolymph and vitellogenin transcript abundance in fat body of stingless bee workers are difficult to reconcile in a straightforward manner with the predictions from kin selection theory on worker reproduc- tion. With few exceptions, stingless bee colonies are headed by a single queen that has mated with a single male (Paxton et al., 1999; Peters et al., 1999), and this sociogenetic constellation would favor male production by workers (Crozier and Pamilo, 1996). Quite amazingly though, there is hardly anything more variable than the pattern of reproductive activity in workers of stingless bees, which ranges from a strong worker contribution to male production to complete worker sterility (Silva-Matos et al., 2000). A main complicating factor in our comprehension of worker fertility in stingless bees is the production of trophic eggs that workers of many species produce in addition to or instead of reproductive eggs. These trophic eggs are laid during the POP process and are generally consumed by the queen (Akahira et al., 1970), thus, helping her to maintain her own optimum reproductive activity (for review see, Sakagami, 1982; Engels and Imperatriz-Fonseca, 1990). Whereas oophagy is a common feature in social insects, used by dominant females to monopolize colony reproduction, stingless bees have clearly gone one step further, so as to make the production of trophic eggs a constitutive feature of colony integration in many genera. This evolutionary trend is evident in the fact that trophic eggs differ from reproductive eggs in many aspects, they are not only bigger and have a modified chorion structure, they also appear to be cytochemically immature and possibly have even lost the oocyte nucleus (Akahira et al., 1970; Cruz-Landim and Cruz-Höfling, 1971; Koedam et al., 1996).

The reproductive potential and activity of workers in the normal colony context, i.e. in the presence of the queen, can roughly be divided into five classes: (I) workers are totally incapable of producing eggs of any type, (II) workers produce eggs but do not lay them, (III) workers produce/lay primarily trophic eggs, (IV) workers produce/lay primarily reproductive eggs, and $(\mathrm{V})$ workers produce and lay both types of eggs. The first class is best represented by the genus Frieseomelitta, where ovaries have been shown to start developing normally during the larval stages, but then they degenerate completely during pupal development (Boleli et al., 1999, 2000). As a consequence, no germ cells are left and, in fact, the adult gonads show the cytological characteristics of a storage organ. Examples for the other classes are shown in 
Table I. Obviously, these different modes of egg production by workers have consequences on individual and colony fitness, since it is only the workers of categories IV and V that can and will contribute significantly to the production of males (Beig, 1972; Contel and Kerr, 1976; Toth et al., 2004; Velthuis et al., 2005).

In physiological and cell biological terms, the way that trophic eggs are produced is still a little understood phenomenon. Their role, however, is fairly clear, namely to provide the queen with a protein- and lipid-rich diet so that she can sustain the high levels of vitellogenin synthesis in her fat body. In this respect, the stingless bees differ from the honey bees which feed the queen trophallactically with glandular secretions. Yet, the detection of vitellogenin receptor-like proteins on the hypopharyngeal gland of honey bee workers suggests that this protein may actually be taken up from the hemolymph and converted by the gland into royal jelly proteins (Amdam et al., 2003). In the honey bee, the vitellogenin transfer from nursestage workers to the queen would, thus, pass through the hypopharyngeal gland secretions, while in the stingless bees it is passed on directly through the trophic eggs. This may be partly a consequence of, or at least coherent with the restriction imposed on reproductive activity of workers in honey bees, where the polyandrous mating system apparently has resulted in a suppression of ovarian activity through queen pheromones on the one hand and worker policing on the other.

This does not mean, of course that trophic eggs are the exclusive source of nutrition for queens of stingless bees, especially since there are species were egg production in workers is rare to absent. Queens do not only feed on trophic eggs but also have frequently been observed to insert their heads into newly provisioned brood cells and, thus, may consume some of the larval food before laying an egg (Sakagami, 1982).

\section{CONCLUDING REMARKS AND PERSPECTIVES}

Their variability in natural history and the phylogenetic proximity to the honey bee, the model organism for polyphenism and division of labor in the social Hymenoptera, makes stingless bees excellent candidates for comparative studies. In addition, the genus Melipona presents a long-time enigma for its mechanism of caste determination that is now being deciphered with respect to underlying genetic and physiological mechanisms. The comparative approaches in hormone and gene expression analyses also gradually reveal where and to what extent the regulatory machinery of insect development is conserved in the eusocial bees, and at which point development can be sufficiently plastic to drive the differentiation of polyphenic traits.

A particularly interesting facet is the emergent parallelism between caste determination and sex determination, both of which exhibit transitions from environmental to genetic mechanisms of determination. Whilst the transition from environmental (ESD) to genetic sex determination (GSD) is an ancient and recurrent phenomenon in different lines of metazoans (Bull, 1981; Sarre et al., 2004; Yao and Capel, 2005), the transition from environmental to genetic caste determination (ECD to GCD) is, obviously, a much more recent event associated with socioevolution in insects, and there are only few examples in bees (the genus Melipona) and in ants (Winter and Buschinger, 1986; Fraser et al., 2000; Julian et al., 2002; Volny and Gordon, 2002; Helms Cahan and Keller, 2003). In this sense, the ECD-GCD transition in social insect castes, as well as other transitions from environmental to genetic determination of seasonal polyphenisms, for instance in butterfly color patterns (for review see, Hartfelder and Emlen, 2005) can serve as scenarios that illustrate how environmental signals and genetic factors become interchangeable in terms of their impact on developmental pathways (West-Eberhard, 2003). This interchangeability depends on ganged switch mechanisms triggered by environmental or genetic factors. In caste development, such switches are manifest in the caste-specific hormone titers that drive character expression in morphogenetic fields.

An intriguing consequence of the apparent ECD-GCD transition in stingless bees is the high percentage of gynes produced in Melipona colonies under favorable colony conditions, and the way workers eventually adjust queen production to the colony reproductive cycle. 
Gynes are kept in reserve for some days and most are then eventually killed (Engels and Imperatriz-Fonseca, 1990). This is a 'tragedy of the commons' (Wenseleers and Ratnieks, 2004) in a double sense, not only for each individual superfluous gyne, but also in terms of colony investment.

Another interesting facet in the castes of stingless bees is the fact that stingless bee workers are morphologically more similar to males than to queens (Kerr, 1974, 1987, 1990a), quite opposite to what is observed in honey bees. And this male/worker similarity in stingless bees is not only one of phenotype, but there are also reports on similarities in behavior. Males of stingless bees have been reported to sporadically perform activities related to colony maintenance, such as nectar dehydration, wax manipulation and others (Nogueira-Neto, 1997; Van Veen et al., 1997; Velthuis et al., 2005). If verified consistently, this not only has implications on sociobiological interpretations of caste systems in Hymenoptera (Kerr, 1990b), but, more directly, it also raises the question on how task performance is physiologically regulated and integrated in stingless bees, and whether they are distinct from honey bees in this respect.

The physiological background to age-related behavioral development in bees involves characteristic changes in the juvenile hormone titer and in the expression of the yolk protein precursor vitellogenin. Even though still preliminary, the emergent results on juvenile hormone titers and vitellogenin expression in adult workers in stingless bees indicate that the highly eusocial bees differ significantly in these prime components of the reproductive groundplan of female insects. In honey bees, the vitellogenin and $\mathrm{JH}$ titer have been mathematically modeled as a double repressor constellation for division of labor (Amdam and Omholt, 2003) and this constellation has recently been experimentally confirmed through a vitellogenin gene silencing approach by RNA interference (Guidugli et al., 2005). In contrast, stingless bee workers appear to constitutively transcribe the vitellogenin gene, to maintain a low $\mathrm{JH}$ titer throughout adult life (see preliminary results presented above), and to show a much more flexible age-related pattern of task performance (Waldschmidt and Campos, 1997). The only clear similarity we could note in hormone titers in adult workers of meliponine and apine bees is the minor peak detectable in very young workers, which can be interpreted as a prerequisite to adult maturation. The currently emerging results on regulatory mechanisms underlying caste development and reproductive physiology in stingless bees, thus, clearly illustrate the potential of this large and variable group of bees for comparative studies. And it is through such comparative studies that we can expect to gain insight into evolutionary trends in developmental and reproductive plasticity in social insects.

\section{ACKNOWLEDGEMENTS}

We thank Paulo Nogueira Neto for kindly providing some of the Melipona quadrifasciata colonies used in our experiments cited above, and we acknowledge financial support by Fundação de Amparao a Pesquisa do Estado de São Paulo (FAPESP), Conselho Nacional de Desenvolvimento Científico e Tecnológico (CNPq), Coordenação de Aperfeiçoamento de Pessoal de Nível Superior (CAPES), and the Deutsche Akademische Austauschdienst (DAAD).

Résumé - Mécanismes physiologiques et génétiques sous-tendant le développement des castes, la reproduction et la division du travail chez les abeilles sans aiguillon. Le nombre d'espèces et la variabilité des caractères écologiques et éthologiques rendent les abeilles sans aiguillon remarquables et en font un groupe intéressant pour rechercher des corrélations entre les caractères du cycle évolutif d'une part et les mécanismes physiologiques et génétiques qui sous-tendent le développement des castes, la reproduction et la division du travail d'autre part. Dans cette synthèse nous mettons en contraste les nombreuses observations sur les abeilles sans aiguillon avec celles de leur groupe sœur, les abeilles domestiques.

Toutes les abeilles sans aiguillon approvisionnent en masse les cellules de leur couvain avant que la reine ne ponde un ouf et ne l'opercule. Il y a néanmoins des différences remarquables dans la structure du nid à couvain et dans la manière dont les reines, les ouvrières et les mâles sont élevés (Fig. 1). Dans le groupe des trigones, les reines sont produites dans de grandes cellules à couvain ou dans des cellules construites les unes sur les autres, ce qui permet aux larves d'ingérer beaucoup plus de nourriture. Dans le genre Melipona au contraire, toutes les cellules de couvain sont de même taille et un nombre relativement élevé de reines émerge de ces cellules dans des conditions optimales de la colonie. Cette observation a conduit à émettre l'hypothèse que la détermination des castes chez Melipona a peut-être une base génétique. Bien qu'elle ait été proposée il y a plus de 50 ans, 
cette hypothèse n'a jamais été validée de façon concluante. Selon les recherches en cours, les marqueurs génétiques générés par un protocole AFLP se séparent en fonction du phénotype de la caste (Fig. 2). D'autres preuves proviennent d'une analyse de l'expression génique différentielle sur des reines récemment écloses et des ouvrières de Melipona quadrifasciata. Cette étude a été produite sur 1200 ESTs (étiquettes de séquences exprimées) qui ont été comparées aux profils d'expression génique spécifiques des castes chez Apis mellifera, soulignant l'importance de la régulation métabolique dans le développement des castes. Nous avons testé les profils d'expression de cinq des gènes représentés par les ESTs dans une comparaison entre reines naturelles et ouvrières et reines induites par un traitement hormonal des larves au stade de filage du cocon; nous avons constaté que les adultes issus des larves traitées par hormones sur-exprimaient la plupart de ces gènes marqueurs, même s'ils présentaient le phénotype de reine (Fig. 3). Ceci indique que le phénotype morphologique et le profil d'expression génique ne concordent pas nécessairement.

Il existe aussi chez les abeilles sans aiguillon une forte variation en ce qui concerne la reproduction des ouvrières, certaines espèces présentant une contribution significative des ouvrières à la production des mâles. Chez de nombreuses espèces, les ouvrières produisent des œufs trophiques qui sont consommés par la reine peu de temps avant qu'elle ne ponde dans une cellule fraîchement approvisionnée. Chez certaines espèces, pourtant, la reproduction des ouvrières est complètement bloquée par la dégénérescence des ovaires au cours du développement nymphal. Ces différences dans les stratégies de reproduction des ouvrières se reflètent dans les différences de l'expression génique de la vitellogénine et dans les teneurs de l'hémolymphe en vitellogénine. (Fig. 4). Le résultat le plus frappant se rencontre chez Frieseomelitta, où les ouvrières présentent une expression constitutive de la vitellogénine même si elles sont complètement stériles, indiquant par là des fonctions alternatives pour ce précurseur de la protéine du vitellus. Des résultats préliminaires sur l'hormone juvénile et les teneurs en ecdystéroïde chez les ouvrières adultes de $M$. quadrifasciata montrent aussi des différences considérables avec le paradigme du développement comportemental de l'abeille domestique. Les résultats qui se dégagent actuellement concernant les mécanismes de régulation qui sous-tendent le développement des castes et la physiologie de la reproduction chez les abeilles sans aiguillon illustrent clairement le potentiel de ce groupe d'abeilles, vaste et varié, pour des études comparatives.

abeille sans aiguillon / développement des castes / hormone juvénile / vitellogénine / reproduction des ouvrières / Meliponini
Zusammenfassung - Physiologische und genetische Mechanismen in der Kastenentwicklung, Reproduktion und Arbeitsteilung bei stachellosen Bienen. Stachellose Bienen sind bemerkenswert hinsichtlich ihrer Artenvielfalt und ihrer Variabilität in ökologischen und Verhaltensmerkmalen. Dies macht sie zu einer interessanten Gruppe für Untersuchungen zu korrelativen Verbindungen zwischen Life History Merkmalen auf der einen Seite und physiologischen und genetischen Mechanismen der Kastenentwicklung, differentiellen Reproduktion und Arbeitsteilung auf der anderen. In diesem Übersichtsartikel werden wir viele Beobachtungen an stachellosen Bienen mit denen an Honigbienen gegenüberstellen.

Alle stachellosen Bienen massenverproviantieren ihre Brutzellen kurz bevor die Königin ein Ei ablegt und die Brutzelle danach verschlossen wird und bleibt. Trotz dieses gemeinsamen Merkmals zeigen sie jedoch beachtliche Variabilität hinsichtlich der Neststruktur und in der Art und Weise wie Königinnen, Arbeiterinnen und Männchen aufgezogen werden (Abb. 1). Die gemeinhin unter dem Begriff Trigoninen zusammengefassten Genera produzieren Königinnen in vergrösserten Brutzellen oder in Brutzellen, die eng übereinandergebaut wurden. Im Gegensatz hierzu sind die Brutzellen des Genus Melipona alle von gleicher Grösse und es schlüpfen eine vergleichsweise grosse Anzahl von Jungköniginnen aus deren Brutwaben. Diese Beobachtung hat zu der Hypothese Anlass gegeben, dass die Kastendetermination bei Melipona eine genetische Komponente beinhalten könnte. Obwohl diese Hypothese nun schon vor über 50 Jahren formuliert wurde, konnte sie nie schlüssig belegt werden. Laufende Studien basierend auf einem AFLP-Protokoll lieferten nun erstmals genetische Marker, die mit den Kastenphänotypen segregieren (Abb. 2). Weitere Evidenzen für eine genetische Grundlage der Kastendeterminierung kamen nun auch aus Analysen zur differentiellen Genexpression an frischgeschlüpften Königinnen und Arbeiterinnen von Melipona quadrifasciata. Diese Studie produzierte über 1200 ESTs, die mit kastenspezifischen Genexpressionsmustern bei Apis mellifera verglichen werden konnten. Dabei wurde die Bedeutung der metabolischen Regulation in der Kastenbildung klar herausgestellt. Als wir dann die Expressionsmuster von fünf der durch ESTs repräsentierten Gene von Melipona Arbeiterinnen und Königinnen auch an Königinnen testeten, die durch Juvenilhormon-Applikation in der Spinnmadenphase produziert worden waren, zeigten die meisten dieser Gene ein Expressionsmuster, das weit mehr mit dem von Arbeiterinnen übereinstimmte als mit dem von natürlichen Königinnen (Abb. 3). Dies weist darauf hin, dass der morphologische Phänotyp nicht notwendigerweise kongruent ist mit den Genexpressionsmustern.

Auch hinsichtlich der Arbeiterinnenreproduktion zeigen stachellose Biene eine ausgeprägte Variabilität, und bei manchen Arten produzieren Arbeiterinnen einen Grossteil der Männchen. Bei vielen 
Arten legen Arbeiterinnen sogenannte Nähreier, die von der Königin kurz vor der eigenen Eiablage in einer frischverpoviantierten Brutzelle verzehrt werden. Bei anderen Arten hingegen, ist die Arbeiterinnenreproduktion bedingt durch die Degeneration der Ovarien schon während der Puppenphase vollständig blockiert. Diese Unterschiede in den Reproduktionsstrategien der Arbeiterinnen traten auch in der Expression des Vitellogenin-Gens und der Vitellogenin-Titer bei Arbeiterinnen zutage (Abb. 4). Mit einer der interessantesten Befunde war die konstitutive Expression des Vitellogenin-Gens und ein konstant hoher Vitellogenin-Titer bei Frieseomelitta varia Arbeiterinnen, obwohl diese vollständig steril sind. Dies weist auf alternative Funktionen von Vitellogenin in der Biologie dieser Bienen hin. Vorläufige Ergebnisse zu den Juvenilhormon- und Ecdysteroid-Titern bei adulten Arbeiterinnen von Melipona quadrifasciata weisen ebenfalls auf erhebliche Abweichungen von dem für die Honigbiene erstellten Paradigma der Verhaltensentwicklung hin. Diese neuen Ergebnisse zu regulatorischen Mechanismen in der Kastenentwicklung und Reproduktionsphysiologie stachelloser Bienen illustrieren das hohe Potential dieser artentreichen und vielfältigen Gruppe für vergleichende Studien über soziale Bienen.

\section{Stachellose Bienen / Kastenentwicklung / Juvenil- hormon / Vitellogenin / Arbeiterinnenreproduk- tion}

\section{REFERENCES}

Akahira Y., Sakagami S.F., Zucchi R. (1970) Die Nähreier von Arbeiterinnen einer stachellosen Biene, Trigona (Scaptotrigona) postica, die von der Königin kurz vor der eigenen Eiablage gefressen werden, Zool. Anz. 185, 85-93.

Amdam G.V., Omholt S.W. (2002) The regulatory anatomy of honeybee lifespan, J. Theor. Biol. 21, 209-228.

Amdam G.V., Omholt S.W. (2003) The hive bee to forager transition in honeybee colonies: the double repressor hypothesis, J. Theor. Biol. 223, 451-464.

Amdam G.V., Norberg K., Hagen A., Omholt S.W. (2003) Social exploitation of vitellogenin, Proc. Natl Acad. Sci. USA 100, 1799-1802.

Amdam G.V., Hartfelder K., Norberg K., Hagen A., Omholt S.W. (2004) Altered physiology in worker bees infested with Varroa destructor as a factor in colony loss during overwintering, J. Econ. Entomol. 97, 741-747.

Barchuk A.R., Bitondi M.M.G., Simões Z.L.P. (2002) Effects of juvenile hormone and ecdysone on the timing of vitellogenin appearance in hemolymph of queen and worker pupae of Apis mellifera, Insect Sci. 2.1, 8 p., http://www.insectscience.org/ 2.1/ (accessed on 20 January 2006).
Barchuk A.R., Maleszka R., Simões Z.L.P. (2004) Apis mellifera ultraspiracle: cDNA sequence and rapid up-regulation by juvenile hormone, Insect Mol. Biol. 13, 459-467.

Bego L.R. (1982) On social regulation in Nannotrigona (Scaptotrigona) postica with special reference to male production cycles (Hym., Apidae, Meliponinae), Bolm. Zool. Univ. São Paulo 7, 181-196.

Beig D. (1972) The production of males in queenright colonies of Trigona (Scaptotrigona) postica, J. Apic. Res. 11, 33-39.

Bloch G., Wheeler D.E., Robinson G.E. (2002) Endocrine influences on the organization of insect societies, in: Pfaff D.W., Arnold A.P., Ettgen A.M., Fahrbach S.E., Rubin R.T. (Eds.), Hormones, Brain, and Behavior, Academic Press, San Diego, Vol. 3, pp. 195-237.

Boleli I.C., Simões Z.L.P., Bitondi M.M.G. (1999) Cell death in ovarioles causes permanent sterility in Frieseomelitta varia workers bees, J. Morphol. 242, 271-282.

Boleli I.C., Simões Z.L.P., Bitondi M.M.G. (2000) Regression of the lateral oviducts during the larval-adult transformation of the reproductive system of Melipona quadrifasciata and Frieseomelitta varia, J. Morphol. 243, 141-151.

Bonetti A.M., Cruz-Landim C., Kerr W.E. (1994) Sex determination in bees. XXX. Effects of juvenile hormone on the development of tergal glands in Melipona, J. Apic. Res. 33, 11-14.

Bonetti A.M., Kerr W.E., Matusita S.H. (1995) Effects of juvenile hormones I, II and III, in single and fractionated doses in Melipona bees, Rev. Bras. Biol. 55 (Suppl. 1), 113-120.

Bull J.J. (1981) Evolution of environmental sex determination from genotypic sex determination, Heredity 47, 173-184.

Buschini M.L.T., Campos L.A.O. (1995) Caste determination in Trigona spinipes (Hymenoptera; Apidae): Influence of the available food and the juvenile hormone, Rev. Brasil. Biol. 55 (Suppl. 1), 121-129.

Camargo C.A. (1972a) Determinação de castas em Scaptotrigona postica Latreille (Hymenoptera, Apidae), Rev. Brasil. Biol. 32, 133-138.

Camargo C.A. (1972b) Mating of the social Melipona quadrifasciata under controlled conditions (Hymenoptera, Apidae), J. Kans. Entomol. Soc. $45,520-523$.

Camargo C.A., Almeida M.A.G., Parra M.G.N., Kerr W.E. (1976) Genetics of sex determination in bees. IX. Frequencies of queens and workers from larvae under controlled conditions (Hymenoptera: Apoidea), J. Kans. Entomol. Soc. 49, 120-125.

Cameron S.A., Robinson G.E. (1990) Juvenile hormone does not affect division of labor in bumble bee colonies (Hymenoptera, Apidae), Ann. Entomol. Soc. Am. 83, 626-631.

Campos L.A.O. (1978) Sex determination in bees. VI. Effect of a juvenile hormone analogue in males 
and females of Melipona quadrifasciata (Apidae), J. Kans. Entomol. Soc. 51, 228-234.

Campos L.A.O. (1979) Determinação do sexo em abelhas. XIV. Papel do hormônio juvenil na diferenciação das castas na subfamilia Meliponinae (Hymenoptera: Apidae), Rev. Brasil. Biol. 39, 965-971.

Campos L.A.O., Velthuis H.H.W., Velthuis-Kluppell F.M. (1975) Juvenile hormone and caste determination in a stingless bee, Naturwissenschaften 62, 98-99.

Campos L.A.O., Drummond M.S., Lacerda L.M. (1983) Sex determination in bees. The role of juvenile hormones I, II and III in caste determination in Scaptotrigona xanthotrica (Hymenoptera, Apidae), Ciência Cultura 35, 209-211.

Cash A.C., Whitfield C.W., Ismail N., Robinson G.E. (2005) Behavior and the limits of genomic plasticity: power and replicability in microarray analysis of honeybee brains, Genes Brains Behav. 4, 267-271.

Chinh T.X., Grob G.B.J., Meeuwsen F., Sommeijer M.J. (2003) Patterns of male production in the stingless bee Melipona favosa (Apidae, Meliponini), Apidologie 34, 161-170.

Contel E.P.B., Kerr W.E. (1976) Origin of males in Melipona subnitida estimated from data of an isozymic polymorphic system, Genetica 46, 271277.

Corona M., Estrada E., Zurita M. (1999) Differential expression of mitochondrial genes between queens and workers during caste determination in the honeybee Apis mellifera, J. Exp. Biol. 202, 929-938.

Crozier R.H., Pamilo P. (1996) Evolution of Social Insect Colonies - Sex Allocation and Kin Selection, Oxford University Press, Oxford.

Cruz-Landim C., Cruz-Höfling M.A. (1971) Cytochemical and ultrastructural studies on eggs from workers and queens of Trigona, Rev. Bras. Pesq. Med. Biol. 4, 19-25.

Cruz-Landim C., Santos S.M.F.D., Cruz-Höfling M.A. (1980) Sex determination in bees. XV. Identification of queens of Melipona quadrifasciata anthidioides (Apidae) with the worker phenotype by a study of the tergal glands, Rev. Brasil. Genet. 3, 295-302.

Elekonich M.M., Jez K., Ross A.J., Robinson G.E. (2003) Larval juvenile hormone treatment affects pre-adult development, but not adult age at onset of foraging in worker honey bees (Apis mellifera), J. Insect Physiol. 49, 359-366.

Engels W., Engels E. (1977) Vitellogenin und Fertilität bei Stachellosen Bienen, Insectes Soc. 24, 71-94.

Engels W., Imperatriz-Fonseca V.L. (1990) Caste development, reproductive strategies, and control of fertility in honey bees and stingless bees, in: Engels W. (Ed.), Social Insects - an evolutionary approach to castes and reproduction, Springer Verlag, Berlin, pp. 167-230.
Evans J.D., Wheeler D.E. (1999) Differential gene expression between developing queens and workers in the honey bee, Apis mellifera, Proc. Natl Acad. Sci. USA 96, 5575-5580.

Evans J.D., Wheeler D.E. (2000) Expression profiles during honeybee caste determination, Genome Biol. 2.1, 6, http://genomebiology.com/2000/2/1/ research/0001 (accessed on 20 January 2006).

Evans J.D., Wheeler D.E. (2001) Gene expression and the evolution of insect polyphenisms, Bioessays $23,62-68$.

Faustino C.D., Silva-Matos E.V., Mateus S., Zucchi R. (2002) First record of emergency queen rearing in stingless bees, Insectes Soc. 49, 111-113.

Fraser V.S., Kaufmann B., Oldroyd B.P., Crozier R.H. (2000) Genetic influence on caste in the ant Camponotus consobrinus, Behav. Ecol. Sociobiol. 47, 188-194.

Geva S., Hartfelder K., Bloch G. (2005) Reproductive division of labor, dominance, and ecdysteroid levels in hemolymph and ovary of the bumble bee Bombus terrestris, J. Insect Physiol. 51, 811-823.

Green C.L., Oldroyd B.P. (2002) Queen mating frequency and maternity of males in the stingless bee Trigona carbonaria Smith, Insectes Soc. 49, 196-202.

Grosso A.F., Bego L.R., Martinez A.S. (2000) The production of males in queenright colonies of Tetragonisca angustula angustula (Hymenoptera, Meliponinae), Sociobiology 35, 475-485.

Guidugli K.R., Hepperle C., Hartfelder K. (2004) A member of the short-chain dehydrogenase/ reductase (SDR) superfamily is a target of the ecdysone response in honey bee (Apis mellifera) caste development, Apidologie 35, 37-47.

Guidugli K.R., Nascimento A.M., Amdam G.V., Barchuk A.R., Omholt S.W., Simões Z.L.P., Hartfelder K. (2005) Vitellogenin regulates hormonal dynamics in the worker caste of a eusocial insect, FEBS Lett. 579, 4961-4965.

Hartfelder K. (1990) Regulatory steps in caste development of eusocial bees, in: Engels W. (Ed.), Social Insects - an Evolutionary Approach to Castes and Reproduction, Springer, Heidelberg, pp. 245-264.

Hartfelder K. (2000) Arthropoda - Insecta: Caste differentiation, in: Dorn A. (Ed.), Reproductive Biology of Invertebrates - Progress in Developmental Endocrinology, Wiley \& Sons, Chichester, Vol. XB, pp. 185-204.

Hartfelder K., Engels W. (1989) The composition of larval food in stingless bees: evaluating nutritional balance by chemosystematic methods, Insectes Soc. 36, 1-14.

Hartfelder K., Rembold H. (1991) Caste-specific modulation of juvenile hormone III content and ecdysteroid titer in postembryonic development of the stingless bee, Scaptotrigona postica depilis, J. Comp. Physiol. B 160, 617-620.

Hartfelder K., Engels W. (1992) Allometric and multivariate analysis of sex and caste polymorphism in the neotropical stingless bee, Scaptotrigona postica, Insectes Soc. 39, 251-266. 
Hartfelder K., Engels W. (1998) Social insect polymorphism: Hormonal regulation of plasticity in development and reproduction in the honeybee, Curr. Topics Dev. Biol. 40, 45-77.

Hartfelder K., Emlen D.J. (2005) Endocrine control of insect polyphenism, in: Gilbert L.I., Iatrou K., Gill S. (Eds.), Comprehensive Insect Molecular Science, Elsevier, Oxford, Vol. 3, pp. 651-703.

Hartfelder K., Bitondi M.M.G., Santana W.C., Simões Z.L.P. (2002) Ecdysteroid titers and reproduction in queens and workers of the honey bee and of a stingless bee: loss of ecdysteroid function at increasing levels of sociality? J. Insect Physiol. 32, 211-216.

Helms Cahan S., Keller L. (2003) Complex hybrid origin of genetic caste determination in harvester ants, Nature 424, 306-309.

Hepperle C., Hartfelder K. (2001) Differentially expressed regulatory genes in honey bee caste development, Naturwissenschaften 88, 113-116.

Hunt J.H., Amdam G.V. (2005) Bivoltinism as an antecedent to eusociality in the paper wasp genus Polistes, Science 308, 264-267.

Ihering H. von (1903) Biologie der stachellosen Honigbienen Brasiliens, Zool. Jahrb. 29, 179287.

Imperatriz-Fonseca V.L., Kleinert A.D.P. (1998) Worker reproduction in the stingless bee species Friesella schrottkyi (Hymenoptera: Apidae: Meliponinae), Entomol. Gen. 23, 169-175.

Jaycox E.R. (1976) Behavioral changes in worker honey bees (Apis mellifera) after injection with synthetic juvenile hormone (Hymenoptera: Apidae), J. Kans. Entomol. Soc. 49, 165-170.

Judice C., Hartfelder K., Pereira G.A.G. (2004) Castespecific gene expression profile in the stingless bee Melipona quadrifasciata - are there common patterns in highly eusocial bees, Insectes Soc. 51, 352-358.

Judice C., Carazolle M., Festa F., Sogayar M.C., Hartfelder K., Pereira G.A.G. (2006) Gene expression profiles underlying alternative caste phenotypes in a highly eusocial bee, Insect Mol. Biol. 15, 33-44.

Julian G.E., Fewell J.H., Gadau J., Johnson R.A., Lorrabee D. (2002) Genetic determination of the queen caste in an ant hybrid zone, Proc. Natl Acad. Sci. USA 99, 8157-8160.

Kerr W.E. (1946) Formação de castas no gênero Melipona (Illiger, 1806) - nota prévia, Anais Esc. Sup. Agric. "Luiz de Queiroz" 3, 299-312.

Kerr W.E. (1948) Estudos sobre o gênero Melipona, Anais Esc. Sup. Agric. "Luiz de Queiroz" 5, 181291.

Kerr W.E. (1950a) Evolution of the mechanism of caste determination in the genus Melipona, Evolution 4, 7-13.

Kerr W.E. (1950b) Genetic determination of castes in the genus Melipona, Genetics 35, 143-152.

Kerr W.E. (1969) Some aspects of the evolution of social bees, in: Dobzhansky T., Hecht M.K.
(Eds.), Evolutionary Biology, Appleton-CenturyCrofts, New York, Vol. 3, pp. 119-175.

Kerr W.E. (1974) Sex determination in bees. III. Caste determination and genetic control in Melipona, Insectes Soc. 21, 357-368.

Kerr W.E. (1987) Sex determination in bees. XVII. Systems of caste determination in the Apinae, Meliponinae and Bombinae and their phylogenetic implications, Rev. Brasil. Genet. 10, 685-694.

Kerr W.E. (1990a) Sex determination in bees. XXVI. Masculinism of workers in the Apidae, Rev. Brasil. Genet. 13, 479-489.

Kerr W.E. (1990b) Why are workers in social Hymenopetera not males? Braz. J. Genet. 13, 13136.

Kerr W.E., Nielsen R.A. (1966) Evidences that genetically determined Melipona queens can become workers, Genetics 54, 859-866.

Kerr W.E., Stort A.C., Montenegro M.S. (1966) Importância de alguns fatores ambientais na determinação das castas do gênero Melipona, Anais Acad. Brasil. Ciências 38, 149-168.

Koedam D., Velthausz P.H., van de Krift T., Dohmen M.R., Sommeijer M.J. (1996) Morphology of reproductive and trophic eggs and their controlled release by workers in Trigona (Tetragonisca) angustula Illiger (Apidae, Meliponinae), Physiol. Entomol. 21, 289-296.

Koedam D., Contrera F.A.L., Imperatriz-Fonseca V.L. (1999) Clustered male production by workers in the stingless bee Melipona subnitida Ducke (Apidae, Meliponinae), Insectes Soc. 46, 387-391.

Kucharski R., Maleszka R. (2002) Evaluation of differential gene expression during behavioral development in the honeybee using microarray and northern blots, Genome Biol 3.2, 9 p., http://genomebiology.com/2002/3/2/research/0007 (accessed on 20 January 2006).

Maciel-Silva V.L., Kerr W.E. (1991) Sex determination in bess. XXVII. Caste obtained from larvae fed homogeneized food in Melipona compresssipes (Hymenoptera, Apidae), Apidologie 22, 15-19.

Makert G.R., Paxton R.J., Hartfelder K. (2006) An optimized method for the generation of AFLP markers in a stingless bee (Melipona quadrifasciata) reveals a high degree of genetic polymorphism, Apidologie (in press).

Michener C.D. (1974) The Social Behavior of the Bees, Belknap Press of Harvard University Press, Cambridge.

Nogueira-Neto P. (1997) Vida e Criação de Abelhas Indígenas sem Ferrão, Editora Nogueirapis, São Paulo.

O’Donnell S., Reichardt M., Foster R. (2000) Individual and colony factors in bumble bee division of labor (Bombus bifarius nearcticus Handl), Insectes Soc. 47, 164-170.

Paxton R.J., Weisschuh N., Engels W., Hartfelder K., Quezada-Euán J.J.G. (1999) Not only single mating in stingless bees, Naturwissenschaften 86 , $143-146$ 
Paxton R.J., Bego L.R., Shah M.M., Mateus S. (2003) Low mating frequency of queens in the stingless bee Scaptotrigona postica and maternity of males, Behav. Ecol. Sociobiol. 53, 174-181.

Pereboom J.J.M., Jordan W.C., Sumner S., Hammond R.L., Bourke A.F.G. (2005) Differential gene expression in queen-worker caste determination in bumble bees, Proc. R. Soc. B 272, 1145-1152.

Peters J.M., Queller D.C., Imperatriz-Fonseca V.L., Roubik D.W., Strassmann J.E. (1999) Mate number, kin selection and social conflicts in stingless bees and honeybees, Proc. R. Soc. B 266, 379-384.

Pinto L.Z., Hartfelder K., Bitondi M.M.G., Simões Z.L.P. (2002) Ecdysteroid titers in pupae of highly social bees relate to distinct modes of caste development, J. Insect Physiol. 48, 783-790.

Pinto L.Z., Laure M.A.F.B., Bitondi M.M.G., Hartfelder K., Simões Z.L.P. (2003) Ventral nerve cord shortening in a stingless bee (Melipona quadrifasciata anthidioides, Hymenoptera, Apidae) depends on ecdysteroid titer fluctuation and programmed cell death, Int. J. Dev. Biol. 47, 385-388

Piulachs M.D., Guidugli K.R., Barchuk A.R., Cruz J., Simões Z.L.P., Bellés X. (2003) The vitellogenin of the honeybee, Apis mellifera: structural analysis of the cDNA and expression studies, Insect Biochem. Mol. Biol. 33, 459-465.

Raikhel A.S., Brown M.R., Bellés X. (2005) Hormonal control of reproductive processes, in: Gilbert L.I., Iatrou K., Gill S.S. (Eds.), Comprehensive Insect Molecular Science, Elsevier, Amsterdam, Vol. 3, pp. 433-491.

Ratnieks F.L.W. (2001) Heirs and spares: caste conflict and excess queen production in Melipona bees, Behav. Ecol. Sociobiol. 50, 467-473.

Rembold H., Lackner B., Geistbeck J. (1974) The chemical basis of queen bee determinator from royal jelly, J. Insect Physiol. 20, 307-314.

Robinson G.E., Vargo E.L. (1997) Juvenile hormone in adult eusocial Hymenoptera: gonadotropin and behavioral pacemaker, Arch. Insect Biochem. Physiol. 35, 559-583.

Robinson G.E., Strambi C., Strambi A., Feldlaufer M.F. (1991) Comparison of juvenile hormone and ecdysteroid hemolymph titers in adult worker and queen honey bees (Apis mellifera), J. Insect Physiol. 37, 929-935.

Rutz W., Gerig L., Wille H., Lüscher M. (1976) The function of juvenile hormone in adult worker honey bees, Apis mellifera, J. Insect Physiol. 22, 1485-1491.

Sakagami S.F. (1982) Stingless bees, in: Hermann H.R. (Ed.), Social Insects, Academic Press, New York, Vol. 3, pp. 361-423.

Sakagami S.F., Zucchi R. (1963) Oviposition process in a stingless bee, Trigona (Scaptotrigona) postica Latreille, Studia Entomol. 6, 497-510.

Sakagami S.F., Zucchi R. (1974) Oviposition behavior of two dwarf stingless bees, Hypotrigona (Leurotrigona) muelleri and $H$.
(Trigonisca) duckei, with notes on the temporal articulation of oviposition process in stingless bees, J. Fac. Sci. Hokkaido Univ. VI Zool. 1, 361-421.

Sakagami S.F., Beig D., Akahira Y. (1963) Occurrence of ovary developed workers in queenright colonies of stingless bees, Rev. Brasil. Biol. 23, $115-129$.

Sakagami S.F., Camillo C., Zucchi R. (1973) Oviposition behaviour of a Brazilian stingless bee, Plebeia (Friesella) schrottkyi with some remarks on the behavioral evolution of stingless bees, J. Fac. Sci. Hokkaido Univ. VI Zool. 19, 163-189.

Sarre S.D., Georges A., Quinn A. (2004) The ends of a continuum: genetic and temperature-dependent sex determination in reptiles, Bioessays 26, 639645.

Silva D.L.N. (1977) Estudos bionômicos em colônias mistas de Meliponinae (Hymenoptera, Apoidea), Bolm. Zool. Univ. São Paulo 2, 7-106.

Silva-Matos E.V., Noll F.B., Zucchi R. (2000) Sistemas de regulação social encontrados em abelhas altamente eussociais (Hymenoptera; Apidae, Meliponinae). Anais V Encontro sobre Abelhas, Ribeirão Preto, Brazil, pp. 95-101.

Su M.A., Wisotzkey R.G., Newfeld S.J. (2001) A screen for modifiers of decapentaplegic mutant phenotypes identifies lilliputian, the only member of the Fragile-X/Burkitt's Lymphoma family of transcription factors in Drosophila melanogaster, Genetics 157, 717-725.

Sullivan J.P., Jassim O., Fahrbach S.E., Robinson G.E. (2000) Juvenile hormone paces behavioral development in the adult worker honey bee, Horm. Behav. 37, 1-14.

Toth E., Queller D.C., Imperatriz-Fonseca V.L., Strassmann J.E. (2002) Genetic and behavioral conflict over male production between workers and queens in the stingless bee Paratrigona subnuda, Behav. Ecol. Sociobiol. 53, 1-8.

Toth E., Queller D.C., Dollin A., Strassmann J.E (2004) Conflict over male parentage in stingless bees, Insectes Soc. 51, 1-11.

van Doorn A. (1987) Investigations into the regulation of dominance behavior and of the division of labor in bumble bee colonies (Bombus terrestris), Neth. J. Zool. 37, 255-276.

van Veen J.W., Sommeijer M.J., Meeuwsen F. (1997) Behaviour of drones in Melipona (Apidae, Meliponinae), Insectes Soc. 44, 435-447.

Velthuis H.H.W. (1976) Environmental, genetic and endocrine influences in stingless bee caste determination, in: Lüscher M. (Ed.), Phase and caste determination in insects, Pergamon Press, Oxford, pp. 63-70.

Velthuis H.H.W., Velthuis-Kluppell F.M. (1975) Caste differences in a stingless bee, Melipona quadrifasciata Lep., influenced by juvenile hormone application, Proc. K. Ned. Akad. Wet. C 78, 81-94.

Velthuis B.J., Velthuis H.H.W. (1998) Columbus surpassed: Biophysical aspects of how stingless 
bees place an egg upright on their liquid food, Naturwissenschaften 85, 330-333.

Velthuis H.H.W., Koedam D., Imperatriz-Fonseca V. (2005) The males of Melipona and other stingless bees, and their mothers, Apidologie 36, 169-185.

Volny V., Gordon D.M. (2002) Genetic basis for queen-worker dimorphism in a social insect, Proc. Natl Acad. Sci. USA 99, 6108-6111.

Waldschmidt A.M., Campos L.A.O. (1997) Behavioral plasticity of Melipona quadrifasciata (Hymenoptera: Meliponinae), Rev. Brasil. Biol. 58, 25-31.

Wenseleers T., Ratnieks F.L.W. (2004) Tragedy of the commons in Melipona bees, Proc. R. Soc. B 271, S310-S312.

Wenseleers T., Ratnieks F.L.W., Billen J. (2003) Caste fate conflict in swarm-founding social Hymenoptera: an inclusive fitness analysis, J. Evol. Biol. 16, 647-658.

West-Eberhard M.J. (1996) Wasp societies as microcosms for the study of development and evolution, in: Turillazzi S., West-Eberhard M.J. (Eds.), Natural History and Evolution of Paper Wasps, Oxford University Press, Oxford, pp. 290-317.

West-Eberhard M.J. (2003) Developmental Plasticity and Evolution, Oxford University Press, Oxford, New York.

Wheeler D.E. (1986) Developmental and physiological determinants of caste in social Hymenoptera: evolutionary implications, Am. Nat. 128, 13-34.
Whitfield C.W., Band M.R., Bonaldo M.F., Kumar C.G., Liu L., Pardinas J., Robertson H.M., Soares B., Robinson G.E. (2002) Annotated expressed sequence tags and cDNA microarrays for studies of brain and behaviour in the honey bee, Genome Res. 12, 555-566.

Winter U., Buschinger A. (1986) Genetically mediated queen polymorphism and caste determination in the slave-making ant, Harpagoxenus sublaevis (Hymenoptera: Formicidae), Entomol. Gen. 11, 125-137.

Wittwer F., van der Straaten A., Keleman K., Dickson B.J., Hafen E. (2001) Lilliputian: an AF4/FMR2related protein that controls cell identity and cell growth, Development 128, 791-800.

Yao H.H.C., Capel B. (2005) Temperature, genes, and sex: a comparative view of sex determination in Trachemys scripta and Mus musculus, J. Biochem. 138, 5-12.

Zucchi R., Silva-Matos E.V., Nogueira-Ferreira F.H., Azevedo G.G. (1999) On the cell provisioning and oviposition process (POP) of the stingless nomenclature reappraisal and evolutionary considerations (Hymenoptera, Apidae, Meliponinae), Sociobiology 34, 65-86.

Zufelato M.S., Bitondi M.M.G., Simões Z.L.P., Hartfelder K. (2000) The juvenile hormone analog pyriproxyfen affects ecdysteroiddependent cuticle melanization and shifts the pupal ecdysteroid peak in the honey bee (Apis mellifera), Arthropod. Struct. Dev. 29, 111-119. 